\title{
EFFECTS OF IDENTIFYING TRANSFUSIONAL INCIDENTS BY ACTIVE SEARCHING AT A TERTIARY HOSPITAL
}

\author{
EFEITOS DA BUSCA ATIVA NA IDENTIFICAÇÃO DE INCIDENTES \\ TRANSFUSIONAIS EM UM HOSPITAL TERCIÁRIO
}

Rodolfo Daniel de Almeida Soares'; Carolina Lemos de Brito ${ }^{2}$; Gabriela Lia de Aquino Revoredo²; Henrique de Paula Bedaque ${ }^{3}$.

1. Adjunct Professor of Hematology at the Clinical Medicine Department, Federal University of Rio Grande do Norte (UFRN). Natal, RN. Brazil.

2. Physician. Natal-RN. Brazil.

3. Physician, Otorhinolaryngology resident. Federal University of Rio Grande do Norte (UFRN). Natal, RN. Brazil.

Clinical Medicine Department, Federal University of Rio Grande do Norte (UFRN). Brazil.

Financial Support: None.

Conflict of interest: None.

Hematology and Hemotherapy Center at Onofre Lopes University Hospital - Av. Nilo Peçanha, 619A - Petrópolis, Natal - RN CEP: 59012-300

Rodolfo Daniel de Almeida Soares. E-mail: rodolfo.ufrn@gmail.com

Submitted: may 05; accepted after revision: may 12, 2020.

\section{ABSTRACT}

Objective: The present study aims to analyze implementation consequences on active search for incidents related to blood transfusion at Onofre Lopes University Hospital (HUOL) and establish a blood transfusion profile in this facility. Methods: Blood transfusion and TIs registered on Hemotherapy Core at HUOL were counted through SPSS 20, comparing IT/1000 blood transfusion averages between 2012 and 2014. T Test of Student was used to compare data and chi-square $\left(\mathrm{X}^{2}\right)$ and relative risk calculation to associate the use of blood components and risk to develop TI. Results: An increase of TI numbers at HUOL was shown by active searching and its equivalence to reference French and Brazilian services, liked to ANVISA sentinel network. Thus, there was a change in the average rate from $1.86 \mathrm{TI} / 1000$ blood transfusions in 2012 to $5.36 \mathrm{Tl} / 1000$ blood transfusions in 2013 and $5.86 \mathrm{Tl} / 1000$ in $2014(p=0.001)$. It was also observed that the red blood cell concentrate is the fraction with the highest risk of occurrence of TIs ( $p=0.003)$ and the greatest chance of causing any type of $\mathrm{Tl}$ in relation to the other blood products, $\mathrm{RR}=1.848(95 \% \mathrm{Cl} ; 1.042-3.266)$. It was also seen that the infusion of platelet concentrate is related to the allergic reaction $(p<0.01)$, and greater risk compared to other blood components, $\mathrm{RR}=2.746(95 \% \mathrm{Cl} ; 1.477-5.107)$. Conclusion: This study demonstrates active Hemovigilance importance on Tis subnotifications decrease.

Key words: Hemovigilance; Blood transfusion; Side effects; Medical education. 


\section{RESUMO}

Objetivo: O presente estudo tem como objetivo analisar as consequências da implementação da busca ativa de incidentes transfusionais no Hospital Universitário Onofre Lopes (HUOL) e de conhecer o perfil da hemotranfusão deste hospital. Métodos: Contabilizou-se as hemotransfusões e ITs dos registros do Setor de Hemoterapia do HUOL nos anos supracitados e através do SPSS 20 comparou-se as médias de IT/1000 hemotransfusões em 2012 e no biênio 2013-2014. Utilizou-se o Teste T de Student para comparar as médias e os testes de qui-quadrado $\left(\mathrm{X}^{2}\right)$ e cálculo de risco relativo para associar o uso de hemocomponentes e o risco de desenvolver IT. Resultados: Percebeuse aumento da quantidade de ITs no HUOL com a busca ativa, e sua equivalência ao renomado serviço francês e aos serviços brasileiros, vinculados à Rede Sentinela da ANVISA. Logo, constatou-se a mudança da taxa média de 1,86 ITS/1000 hemotransfusões, em 2012, para 5,36 IT/1000 hemotransfusões em 2013 e 5,86 IT/1000 em 2014 ( $p=0,001)$. Observou-se também que o concentrado de hemácias é a fração com maior risco de ocorrência de ITs $(p=0,003)$ e maior chance de ocasionar qualquer tipo de IT em relação aos demais hemocomponentes, RR=1,848 (IC 95\%; 1,042 - 3,276). Também se viu que a infusão de concentrado de plaquetas se relaciona com a reação do tipo alérgica $(p<0,01)$, e maior risco se comparada aos outros hemocomponentes, $R R=2,746$ (IC 95\%; 1,477-5,107). Conclusão: Este estudo mostra a importância da hemovigilância ativa na queda da subnotificação de Its.

Descritores: Hemovigilância; Transfusão sanguínea; Efeitos adversos; Educação médica.

\section{INTRODUCTION}

Blood transfusion is an essential therapy in medicine, which reestablishes the patient's clinical conditions and often guarantees the recovery from potentially serious illnesses. A health professional, who detects the recipient patient and the blood component necessary for this, performs the transfusion and notifies transfusion incidents, performs such practice ${ }^{1}$.

Based on this, during the 1990s, two European countries implemented the hemovigilance service, with France being the pioneer and the most prominent service today. The French organized an alert and search system for any transfusion reactions, improving the safety of these procedures ${ }^{2}$.

In 1996 the United Kingdom launched the SHOT (Serious Hazards of Transfusion) system, which identifies only serious adverse events, categorizing them. Over the years, this project was expanded, when in 2012, more than $99 \%$ of the British hospital network (NHS) was registered in the program, highlighting the effectiveness of this system ${ }^{3}$.

Hemovigilance, on the other hand, appeared in Brazil in 2000, based on the French system, as the set of procedures and practices to verify and process the effects resulting from the transfusion of blood components, whose objective is to identify and notify transfusion incidents ${ }^{4}$. Notification of transfusion reactions is mandatory to ANVISA - National Health Surveillance Agency since the issuance of RDC 151/2001, 
becoming mandatory in 2010 by RDC 34/2014 ${ }^{5}$. The Brazilian hemovigilance system gathers health care establishments, hemotherapy services, health surveillance agencies of states and municipalities and by ANVISA, through the Risk Monitoring Department $(\text { GEMOR) })^{6}$.

Complementing this, ANVISA's Sentinel Services Surveillance sector created the Sentinela Network, whose purpose is to increase the quality of notification of adverse events related to health products and services. Soon, there was an increase in notifications of transfusion incidents (TIs) in Brazil due to the Network.

Despite these efforts, underreporting is still significant in the aforementioned blood surveillance systems. According to Andreu et al, regional heterogeneity was found in the notifications of TIs, ranging from 1.1 to 4.64/1000 blood transfusions, inferring the underreporting in the system ${ }^{7}$. Therefore, the implementation of the hemovigilance service with active search in nosocomial that perform blood transfusion is an eminent alternative to reducing this bias.

In this scenario, the Hemovigilance project at the Onofre Lopes University Hospital arose due to the demand for control of blood transfusions and their possible complications, in addition to the perception of the hematology and hemotherapy team regarding the need for this service, following the national trend ${ }^{8}$. Therefore, in 2013, a group of medical students from UFRN interested in hemotherapy was selected and guided by a hematologist, who started the active search for transfusion incidents (TIs) at the hospital, through daily visits to recipients questioning them those about the signs and symptoms suggestive of TIs, as well as the analysis of the medical records of these patients.

Thus, this avant-garde project in HUOL and Rio Grande do Norte is of paramount importance not only for the hospital mentioned and the population of Rio Grande do Norte, but primarily for Brazilian scientific production on this topic, in view of the still scarce literature on the subject in Brazil. Therefore, after two years of operation of this project, it is necessary to analyze the significance of the active search for transfusion incidents (TIS) in the detection and description of hospital TIs, and to equate them to those registered by other Brazilian hospitals whose hemovigilance is in force. Still, it is interesting to compare the results obtained by hemovigilance in 2013 and 2014 with other similar services in Brazil and in the world, in an analytical and descriptive way.

\section{METHODS}

This study makes a retrospective and prospective, quantitative and descriptive analysis of the work of Hemovigilance at Hospital Universitário Onofre Lopes (HUOL). The relationship between the number of transfusion incidents and the total of blood components transfused monthly at HUOL between the years 2012, before the project 
was retrospectively implemented, and in the years 2013 and 2014, during the active search prospectively, was analyzed

For this, we used blood transfusions performed in the above-mentioned years in all hospital sectors as an inclusion criterion, organized into: wards, surgical center, intensive care unit and hemodialysis sector, as well as transfusion incidents identified by the health team in these sectors and / or by the students of the hemovigilance team with active search. Only outpatient blood transfusions were excluded from our study.

The data were obtained by collecting the total number of blood transfusions performed at HUOL in 2012, 2013 and 2014. The number of transfusion incidents in 2012 was collected from the records in the HUOL Hemotherapy Sector (SH) occurrence book and the Tls of 2013 and 2014 were recorded in spreadsheets by the hemovigilance project. This study included transfusion incidents that occurred within 24 hours of blood transfusion, recorded by the hospital team in the $\mathrm{SH}$ occurrence book and those detected by members of the hemovigilance team. Incidents are identified: inflammatory reaction; acute hemolytic reaction; allergic reaction; bacterial contamination; volume overload and TRALI (Transfusion Related Acute Lung Injury).

Data analysis was performed using the IBM SPSS 20 software, used to compare the means between the rates of transfusion reactions before and after the implementation of active hemovigilance and the Student's T test, which is also used to compare the rate of Tls occurred in the period of hemovigilance with the French reference standard and with Brazilian averages, official and estimated, made available by the Hemovigilance Bulletin $n^{\circ} 7^{9}$.

In addition, chi-square tests $\left(\mathrm{X}^{2}\right)$ and calculation of risk related to the search for possible associations between the use of blood components and the risk of developing Tls, were used. For our analyzes, all the tests chosen were two-tailed and considered significant values of $p<0.05$, both for the relationship between the red blood cell concentrate and the risk of transfusion incident, as well as in the index between the platelet concentrate and the risk of occurring. Allergic reaction. In carrying out this analysis, only the sample related to the period with active hemovigilance carried out prospectively (2013 and 2014) was used.

This analysis is part of an excerpt from the work initiated by the academics of the HUOL Hemovigilance Project. The study was approved by the Research Ethics Committee of Hospital Universitário Onofre Lopes (CAEE: 38202114.0.0000.5292 / protocol approved at CEP: 100196/2014).

Finally, there was no funding whatsoever and all authors deny any conflict of interest. 
Effects of identifying transfusional incidents by active searching at a tertiary hospital Soares RDA, et al

\section{RESULTS}

\section{General view}

Between 2012 and 2014, 12,281 blood components were transfused. Of these, there were 2,151 transfusions in 2012 and 10,130 blood components in the 2013-2014 biennium, in 2896 patients.

Table 1 - List of total blood components transfused in the years 2012, 2013 and 2014. There is no database on the distribution of blood components by sector in 2012.

\begin{tabular}{|c|c|c|c|c|c|}
\hline \multirow[b]{2}{*}{ Year } & \multicolumn{5}{|c|}{ Transfused Blood Components } \\
\hline & RBCC & PC & FP & CRYO & Total \\
\hline \multirow[t]{2}{*}{2012} & 1223 & 496 & 112 & 319 & 2151 \\
\hline & \multicolumn{5}{|c|}{ Infirmary } \\
\hline 2013 & 1461 & 297 & 390 & 421 & 2569 \\
\hline \multirow[t]{2}{*}{2014} & 1148 & 288 & 438 & 165 & 2039 \\
\hline & \multicolumn{5}{|c|}{ Surgical Center } \\
\hline 2013 & 195 & 110 & 100 & 34 & 439 \\
\hline \multirow[t]{2}{*}{2014} & 253 & 133 & 116 & 40 & 542 \\
\hline & \multicolumn{5}{|c|}{ Intensive Care Unit } \\
\hline 2013 & 392 & 366 & 399 & 147 & 1304 \\
\hline \multirow[t]{2}{*}{2014} & 560 & 319 & 262 & 363 & 1504 \\
\hline & \multicolumn{5}{|c|}{ Hemodialysis } \\
\hline 2013 & 190 & 5 & 32 & 2 & 229 \\
\hline 2014 & 259 & 41 & 23 & 2 & 325 \\
\hline
\end{tabular}

Source: Authors data.

Within the sample, a prevalence of $51 \%$ of blood transfusions was observed in the wards, when compared to the Intensive Care Unit (31\%), the Surgical Center (11\%) and Hemodialysis (7\%). Among the types of transfused blood products, about $50 \%$ corresponded to red blood cell concentrate, $20 \%$ to platelet concentrate, $17 \%$ to fresh plasma and $13 \%$ to cryoprecipitate.

As for transfusion incidents, throughout 2012, only four events were recorded. However, the active search identified a total of 51 transfusion incidents, 25 in 2013 and 26 in 2014. The description of the accumulated by type of transfusion reaction is shown in figure 1. 


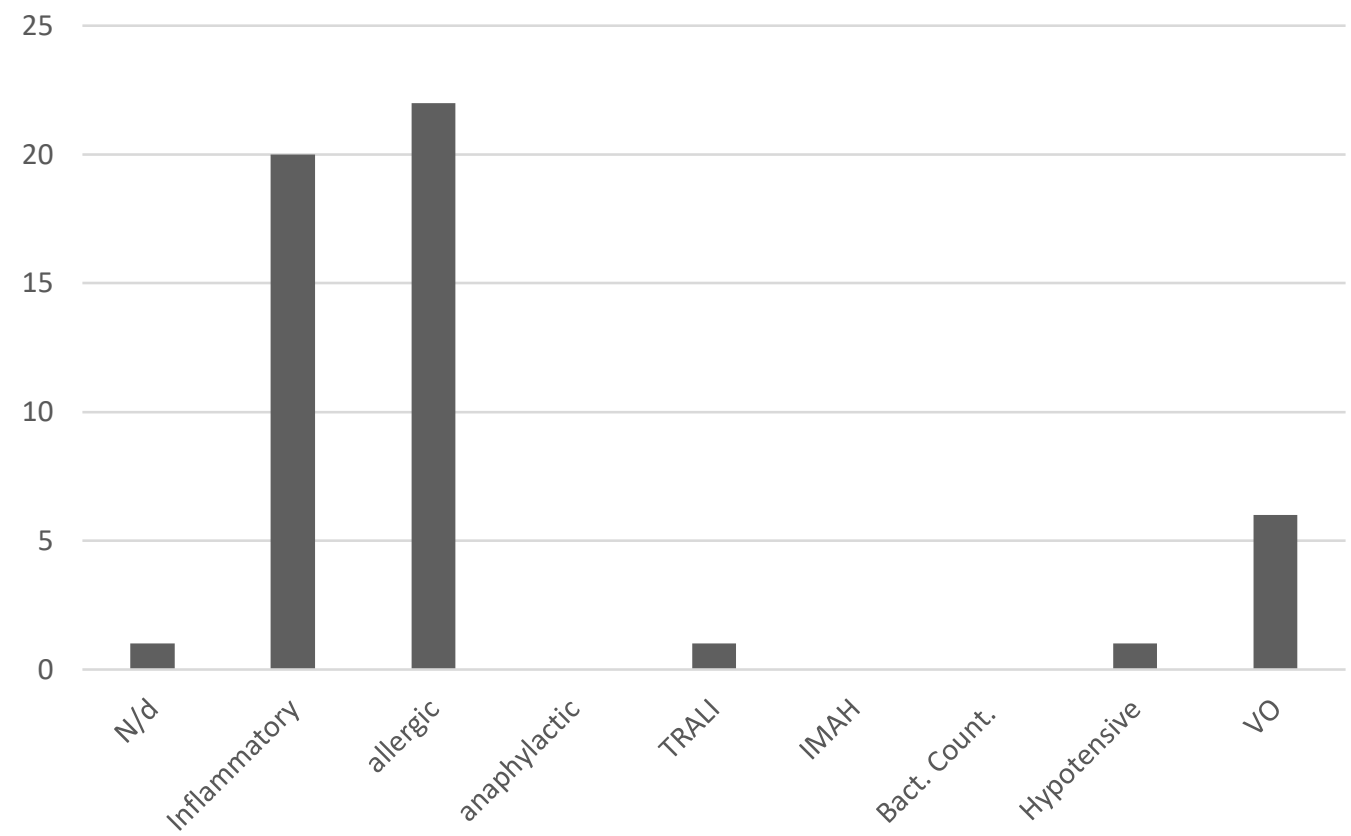

Source: Authors data.

Figure 1 - Description of the absolute number of transfusion incidents by type in the 2013-2014 biennium. N/d: Not declared; Inflammatory/NHF: Non-haemolytic febrile; IMAH: Immuno-mediated Acute Hemolytic, Bact. Count.: Bacterial contamination, VO: Volume overload.

In view of the above, we compared the profile of blood transfusions and TIs in the years in question, as shown in figures 2 and 3.

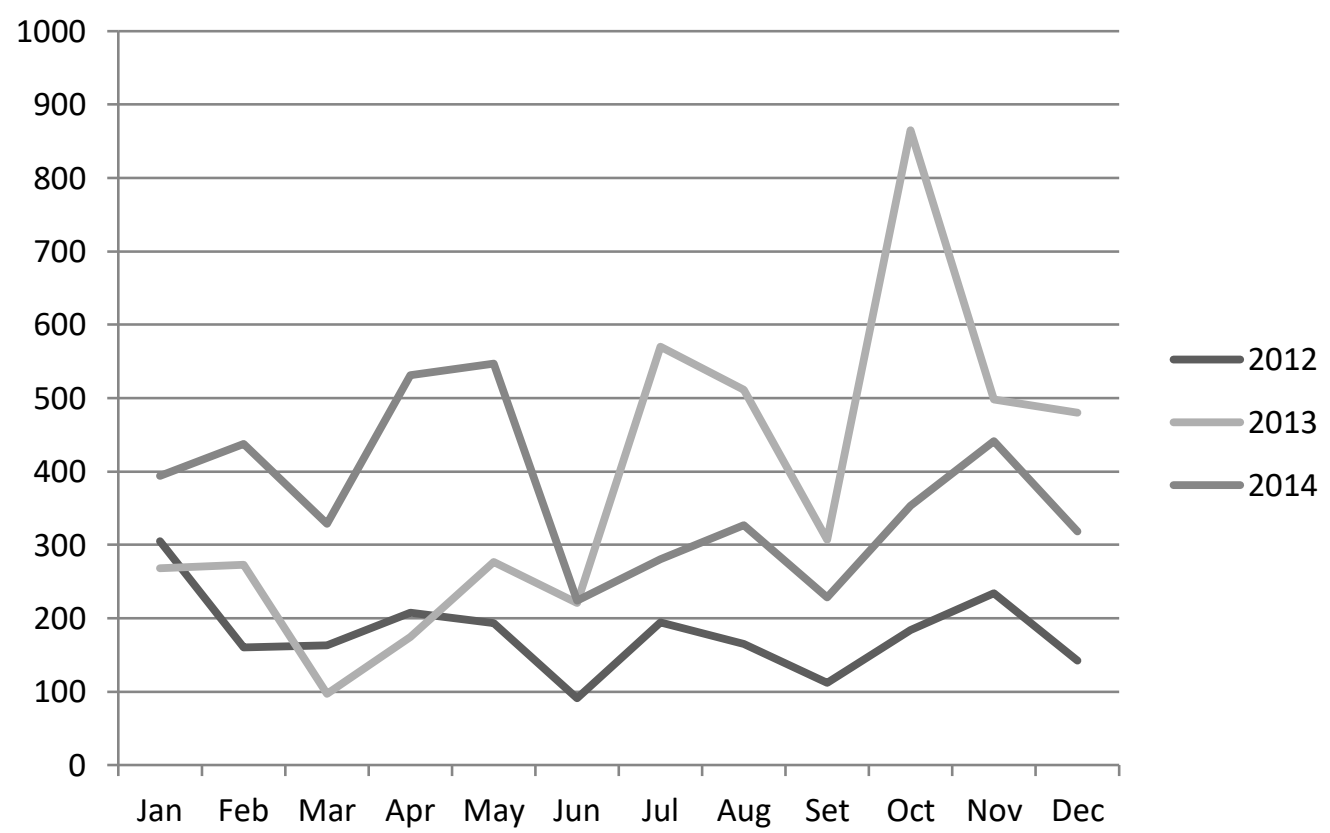

Source: Authors data.

Figure 2 - Annual evolution of the number of blood transfusions at HUOL in the years 2012 to 2014. 


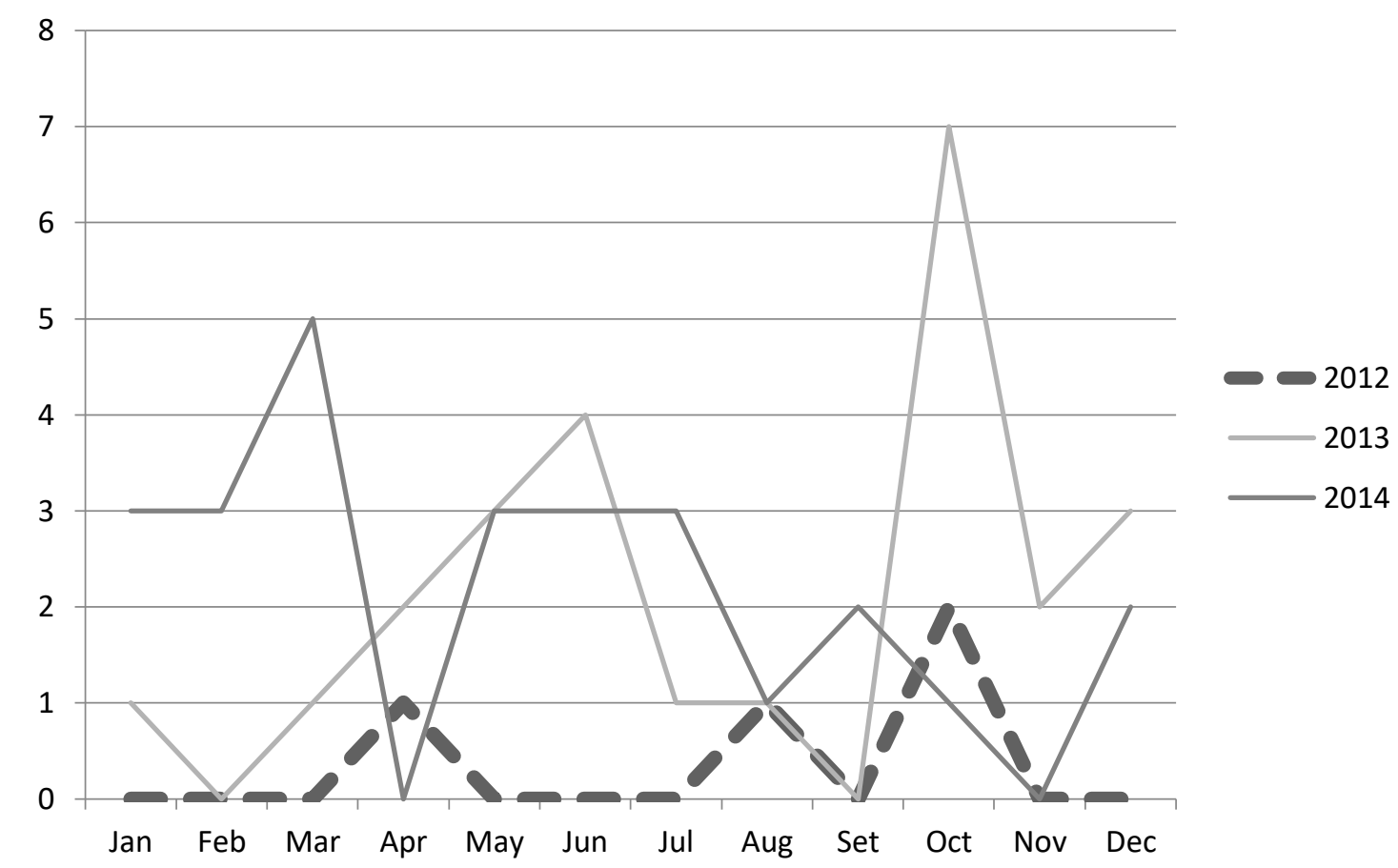

Source: Authors data.

Figure 3 - Annual evolution of the absolute number of transfusion incidents at HUOL in the years 2012 to 2014.

\section{Effects of active searching on Hemovigilance in HUOL}

According to the data obtained, it was possible to demonstrate the work of the active search to increase the detection of transfusion incidents in the hospital. A statistically significant difference was identified between the average rate of 1.86 $\mathrm{TI} / 1000$ blood transfusions in 2012, when there was no hemovigilance, and the years 2013 and 2014 ( $p=0.001$ ), whose averages were $5.06 \mathrm{TI} / 1000$ and $5.66 \mathrm{TI} / 1000$, respectively. (Figure 4). 
Effects of identifying transfusional incidents by active searching at a tertiary hospital Soares RDA, et al

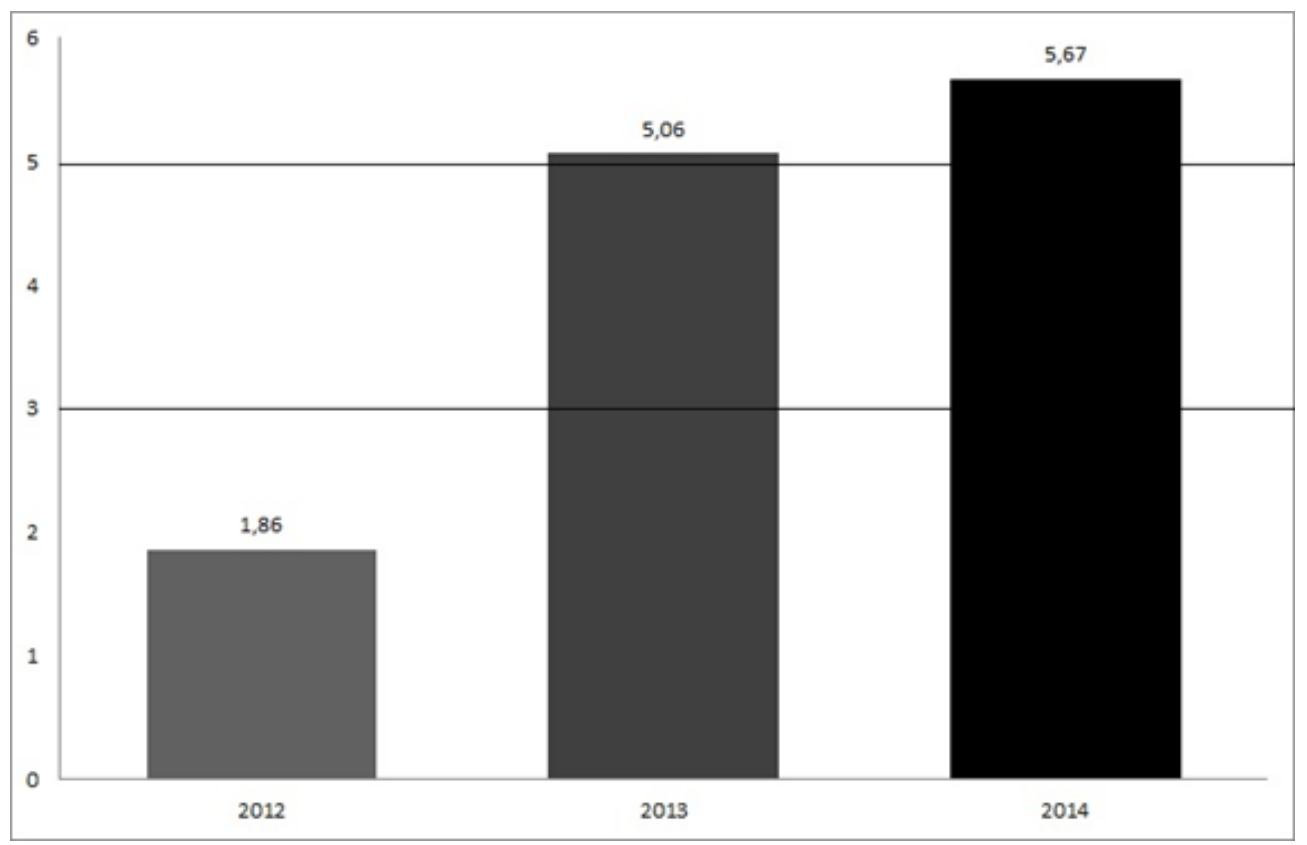

Source: Authors data.

Figure 4 - TI rates for every 1000 blood transfusions for the years 2012 to 2014.

\section{Comparison between HUOL and France}

According to Andreu et $\mathrm{al}^{7}$, the average rate of $\mathrm{Tl} / 1000$ blood transfusions in France is around $3 \mathrm{TI} / 1000$. In this context, since our hemovigilance system is based on the French standard, an analysis was carried out to verify the difference between our rate and the French rate. With the result, it was possible to establish a statistically significant difference between the rates of transfusion incidents $(p=0.012)$. In this context, the average rate found in $\mathrm{HUOL}$ is $5.36 \mathrm{TI} / 1000$ blood transfusions.

\section{Comparison between HUOL and Brazil}

Based on the value found for the average rate of $\mathrm{Tl} / 1000$ blood transfusions during the two years analyzed, the average values of other services were searched in the Brazilian literature. In Callera $\mathrm{F}$ et al, transfusion incidents at the hematology and hemotherapy service in São José dos Campos, São Paulo, were described ${ }^{8}$. In this service, 30 hospitals in the region were included and the rate found was 5.5 per 1000 blood transfusions. In the most recent publication by $\mathrm{ANVISA}^{9}$, the average value between the years 2011 and 2014 in the Rede Sentinela hospitals, despite the locoregional differences and the demand for blood transfusions in the services, is 2.8 / 1000 blood transfusions. However, ANVISA estimates that the most representative rate is $5 \mathrm{Tl} / 1000$ blood transfusions, as this does not consider the effect of underreporting. The present study found a statistically significant difference between the average HUOL rate and the rate calculated for ITs in Brazil $(p=0.007)$ and there is no difference when compared to the estimated average Brazilian rate $(p=0.424)$. 


\section{Relationship between red blood cells and TIs}

In the HUOL blood transfusion service, red blood cell concentrate $(\mathrm{CH})$ is the most transfused blood component in relation to the others, corresponding to $50.2 \%$ (3153) of all blood transfusions in the years 2013 and 2014. In view of the probable association between this blood component and the risk of transfusion incident ${ }^{8}$, it was chosen to evaluate whether in the HUOL sample there is any relationship between $\mathrm{CH}$ transfusion and a higher risk of TI. Thus, this study shows that the use of $\mathrm{CH}$ is related to the risk of developing $\mathrm{TI}(\mathrm{p}=0.003)$, and that the use of $\mathrm{CH}$ leads to a greater risk of any type of $\mathrm{Tl}$ occurring over the other blood components $[\mathrm{RR}=1.848$ ( $95 \% \mathrm{Cl} ; 1.042$ 3.286)].

\section{Relationship between Platelet Concentrate and Allergic Reaction}

Based on the analysis of transfusion incidents by Kato et $\mathrm{al}^{10}$ and their findings about the platelet concentrate, it was decided to evaluate the probability of association between this blood component and the development of a specific type of transfusion incident, the allergic reaction. Thus, the present study found that the $\mathrm{CP}$ infusion is related to the allergic reaction $(p<0.01)$, with a higher risk of allergic reaction being identified for this blood transfusion compared to the other blood products [ $R R=2.746$ ( 95\% Cl; 1.477 - 5.107)].

\section{DISCUSSION}

Whether in the medical clinic or in surgery, it is known that the demand for blood transfusions is significant, and proportional to it, must be medical knowledge on the subject. However, there is a reduced theoretical-practical load in hemotherapy in the curriculum of Brazilian medical students and residents, resulting in unpreparedness in the subject ${ }^{11}$.

Moreover, the active search for transfusion incidents carried out by undergraduate medical students at the Federal University of Rio Grande do Norte and participants in the hemovigilance project is of fundamental importance in the medical graduation of this institution, as it promotes the improvement of clinical skills in hematology and hemotherapy and prepares students from the rational use of blood transfusion, to the careful indication and the management of adverse reactions 12. Furthermore, such a process is crucial in reducing the phenomenon of underreporting, which unfortunately is eminent in Brazil ${ }^{8,9}$.

Therefore, the effects of the aforementioned project on the notification of TIs related to blood transfusions recorded by the hemotherapy service were evaluated. Therefore, analyzing the results described above, it was noticed the statistically significant evolution of the average rate of TIs/1000 blood transfusions between 2012 and the 2013-2014 biennium. Thus, it appears that the implementation of the 
hemovigilance service is indispensable for the identification of these adverse events, as well as for the more appropriate management of patients who develop such complications ${ }^{3,13,14,15}$.

In addition, it is valid to compare the average rate of HUOL with that of Brazil and France, in order to understand whether there is statistical congruence between the services already consolidated. Thus, with regard to Brazil, it was observed that the average rate of HUOL TIs/1000 blood transfusions in 2013 and 2014 is higher than that of ANVISA in the same period, but on the other hand, similar to the rate estimated when one does not consider the underreporting. Therefore, the efficiency of the HUOL's hemovigilance service is verified, even if not registered in the Sentinela Network, since the results are close to those without the effect of underreporting. If compared to France, the average rate of adverse reactions in HUOL is higher than in the French system, the explanation of which is probably due to the technique of Universal Leukoreduction ${ }^{2,7}$ as this consists of the removal of $99.9 \%$ of leukocytes from the original blood component, through specific filters, keeping less than $5 \times 10^{6}$ leukocyte/unit ${ }^{16}$. However, it is worth noting that HUOL's hemovigilance is subject to failures, and the probable causes of underreporting are recognized, whose influence may have influenced the calculations of this study: death or hospital discharge of the recipient patient before the investigation of signs and symptoms of TIs by students, in addition to the non-recording of adverse events by the nursing staff, surgical center, hemodialysis or intensive care unit at HUOL.

In this study, a relationship was observed between the use of $\mathrm{CH}$ and the increase in the occurrence of Tls compared to other blood components. One of the possible contributing factors for this is the fact that our service does not perform Universal Leukorreduction, a practice recommended in the United States and Europe, which reduces the rates of inflammatory reaction caused by $\mathrm{CH}$, an effect that is still controversial in relation to $\mathrm{CP}^{17,18}$. In addition, there was a greater amount of reactions in the wards, concluding that the surveillance and active search for signs and symptoms of ITs in the wards should be more accentuated, not only by the students of the project in hemovigilance, but also by the team of health sector.

That said, and knowing the academic deficiency of the medical course in transfusion incidents, the improvement of learning in this subject is stimulated, with the provision of educational materials and institutional training of the hospital team in the recognition of these reactions, in order to reduce underreporting and polish the management of recipient patients ${ }^{19}$.

In addition to this event, the association between the second most blood transfused blood in the sectors, the platelet concentrate (except in the operating room, where fresh plasma assumes this position) and the development of the allergic reaction (AR) was analyzed. Such analysis is due to the majority of references observing the 
prevalence of RA-type TIs related to CP, as observed by Kato et al and Siegenthaller et $a^{10,15}$, unlike Callera et al, who observed most of the AR in red blood cell concentrate ${ }^{8}$.

Thus, as Xiao et $\mathrm{al}^{20}, 2013$, at HUOL, the occurrence of allergic reactions by PC predominated, the explanation of which probably lies in the atopic susceptibility of the receptor and the permanence of plasma allergen factors in this blood component, due to the storage process, with histamine and biological response modifying factors being the most notable. ${ }^{21}$. In addition, most of the PCs used in our service come from a pool of platelets, that is, blood from 4 to 6 donors, with higher levels of IgE and plasma proteins. Thus, there is an aggravating factor in the occurrence of $A R$, in contrast to the use of platelets by apheresis, originating from a single donor ${ }^{20}$. Therefore, as the CP is the second most transfused blood component, it is necessary to quickly identify this event in order to manage it in an agile and correct manner, preventing sensitization by the recipient, as well as anaphylaxis if the transfused amount is significant and the if the patient already has a history of AR or severe atopy.

Therefore, it is possible to propose some recommendations to be adopted by the HUOL service in the coming years, such as: the use of leukorreduced blood components $^{18}$, because our use is still quite incipient; the use of platelets by apheresis, which reduces the risks of alloimmunization and HLA incompatibility, aggravated by the various $\mathrm{CP}$ transfusions ${ }^{20}$; the rational use of blood components, with the training of doctors since graduation and attention to the appropriate criteria for indication, avoiding excessive blood transfusions and the use of prophylactic measures against adverse reactions according to the recipient's background ${ }^{14}$.

Still in this context, observing the effectiveness of the active search, it is interesting to outline the profile of the HUOL transfusion incidents and to elaborate a screening and TI management protocol for the hospital doctors.

From the present study, the significance of the performance of the hemovigilance project at $\mathrm{HUOL}$ is noticeable, as it represents an advance in the quality of notifications of adverse events, due to the active search for Tls carried out, voluntarily, by the medical students of the project. It is known that TI notifications are indispensable in the construction of the epidemiological profile of the institution's transfusion incidents and that, from that, the multidisciplinary hospital team can create alternatives and strategies in order to reduce the incidence of these events, as well as a protocol of conduct in $\mathrm{TI}$.

Equally, such activity encourages the development of communicative skills and the doctor-patient relationship of undergraduate students, in addition to fostering academic discussion and research in hematology and hemotherapy. Therefore, interventions of this nature should be encouraged, both with medical students and residents, based on the inclusion of classes in the curriculum and events on hemotherapy, aiming to improve and disseminate knowledge in transfusion medicine, 
still little worked in Brazil, thus contributing to the theoretical-practical medical training ${ }^{4,12}$.

\section{REFERENCES}

1. Brasil. Ministério da Saúde: Portaria n॰. 2712, de 12 de novembro de 2013. Redefine o regulamento técnico de procedimentos hemoterápicos. Brasília - DF: D.O.U Diário Oficial da União, Poder Executivo; 2013. [Internet]. 2013 [citado 08 Julho 2016]; Disponível em: http://bvsms.saude.gov.br/bvs/saudelegis/gm/2013/prt2712 1211 2013.html.

2. Hervé $P$, Floris $M$, Rebibo $D$, Morei $P$, Andreu G. Hemovigilance in France. Rev Bras Hematol Hemoter. 2000;22(3):268-73.

3. Bolton-Maggs P, Cohen H. Serious Hazards of Transfusion (SHOT) hemovigilance and progress is improving transfusion safety. Br J Hematol. 2013;163(3):303-314.

4. Flausino GF, Nunes FF, Cioffi JGM, Carneiro-Proietti ABF. O ciclo de produção do sangue e a transfusão: o que o médico deve saber. Rev Med Minas Gerais. 2015; 25(2): 269-79.

5. Brasil. Ministério da Saúde: Resolução da diretoria colegiada (RDC) № 34, 11 de junho de 2014. Dispõe sobre as boas práticas no ciclo do sangue. Brasília - DF: D.O.U - Diário Oficial da União, Poder Executivo; 2014.

6. Brasil. Agência Nacional de Vigilância Sanitária (ANVISA). Relatório de Hemovigilância 2007-2013.1aed. Brasília. 2014. [Internet]. 2014 [citado 20 Agosto 2016]; Disponível em: http://portal.anvisa.gov.br/documents/33868/405222/Relat\%C3\%B3rio+de+Hem ovigil\%C3\%A2ncia+-+Dados+consolidados+2007-+2013/94f9c32d-5a0d-4a8e-a7f0$\underline{425120 \mathrm{e} 1693 \mathrm{c} .}$

7. Andreu G, Morel P, Forestier F, Debeir J, Rebibo D, Janvier G et al. Hemovigilance network in France: organization and analysis of immediate transfusion incident reports from 1994 to 1998. Transfusion. $2002 ; 42(10) 1356-64$.

8. Callera F, Silva A, Moura A, Melo D, Melo C. Descriptions of acute transfusion reactions in a Brazilian Transfusion Service. Rev Bras Hematol Hemoter. 2004; 26(2):78-83.

9. Brasil. Agência Nacional de Vigilância Sanitária (ANVISA). Boletim de Hemovigilância, no7. Brasília. Outubro, 2015. [Internet]. 2015 [citado 6 Agosto 2016];26(2). http://portal.anvisa.gov.br/documents/33868/405222/Boletim+de+Hemovigil\%C3 \%A2ncia+n\%C2\%BA+7/6e7fecae-919c-4b5b-9723-b3552ea0295f.

10. Kato H, Uruma M, Okuyama $Y$, Fujita $H$, Handa $M$, Tomiyama $Y$ et al. Incidence of transfusion-related adverse reactions per patient reflects the potential risk of transfusion therapy in Japan. Am J Cl Pathol. 2013; 140(2):219-24.

11. Vasconcelos M, Cotta-de-Almeida V, Alves L. Transfusion medicine in medical education: an analysis of curricular grids in Brazil and a review of the current literature. Rev Bras Hematol Hemoter. 2016 ;38(3):252-6. 
12. Flausino G, Nunes F, Cioffi J, Proietti A. Teaching transfusion medicine: current situation and proposals for proper medical training. Rev Bras de Hematol Hemoter. 2015;37(1):58-62.

13. Michlig C, Vu D, Wasserfallen J, Spahn D, Schneider P, Tissot J. Three years of haemovigilance in a general university hospital. Transf Med. 2003;13(2):63-72.

14. Mafirakureva N, Khoza S. Mvere, D.A. Chitiyo, D.E. Postma, MJ. Hulst, MV et al. Incidence and pattern of 12 years of reported transfusion adverse events. Blood Transfusion. 2014;12(3):362-7

15. Siegenthaler M, Schneider P, Vu D, Tissot J. Hemovigilance in a general university hospital: need for a more comprehensive classification and a codification of transfusion-related events. Vox Sanguinis. 2005;2016];88(1):22-30.

16. Brasil. Ministério da Saúde Resolução da diretoria colegiada (RDC) no 153, de 14 de junho de 2004. Regulamento Técnico para os procedimentos hemoterápicos, incluindo a coleta, o processamento, a testagem, o armazenamento, o transporte, o controle de qualidade e o uso humano de sangue, e seus componentes, obtidos do sangue venoso, do cordão umbilical, da placenta e da medula óssea. Diário Oficial da União, Poder Executivo;14 Jun 2004. [Internet]. 2004 [citado 8 Julho 2016];44(1):16-24. Disponível em: http://portal.anvisa.gov.br/legislacao/?inheritRedirect=true\#/visualizar/26230

17. Paglino J, Pomper G, Fisch G, Champion M, Snyder E. Reduction of febrile but not allergic reactions to RBCs and platelets after conversion to universal prestorage leukoreduction. Transfusion. 2004;44(1):16-24.

18. King K, Shirey R, Thoman S, Bensen-Kennedy D, Tanz W, Ness P. Universal leukoreduction decreases the incidence of febrile nonhemolytic transfusion reactions to RBCs. Transfusion. 2004;44(1):25-9.

19. Gharehbaghian A, Javadzadeh Shahshahani $H$, Attar $M$, Rahbari Bonab M, Mehran $M$, Tabrizi Namini M. Assessment of physicians knowledge in transfusion medicine, Iran, 2007. Transf Med. 2009;19(3):132-138.

20. Xiao W, Tormey C, Capetillo A, Maitta R. Allergic transfusion reactions to platelets are more commonly associated with prepooled than apheresis components. Vox Sanguinis. 2013;105(4):334-340.

21. Hirayama F. Current undertanding of allergic transfusion reactions: incidence, pathogenesis, laboratory tests, prevention and treatment. Jap J Transf Cell Ther. 2013;59(4):601-12. 